\title{
Analysing English First Additional Language teachers' understanding and implementation of reading strategies
}

\begin{tabular}{|c|c|}
\hline \multicolumn{2}{|c|}{  } \\
\hline \multicolumn{2}{|c|}{$\begin{array}{l}\text { Affiliations: } \\
\text { 'Department of English, } \\
\text { University of Fort Hare, } \\
\text { South Africa }\end{array}$} \\
\hline \multicolumn{2}{|c|}{$\begin{array}{l}\text { 2Department of Applied } \\
\text { Languages, Tshwane } \\
\text { University of Technology, } \\
\text { South Africa }\end{array}$} \\
\hline \multicolumn{2}{|c|}{$\begin{array}{l}{ }^{3} \text { Faculty of Social Sciences, } \\
\text { University of Fort Hare, } \\
\text { South Africa }\end{array}$} \\
\hline \multicolumn{2}{|c|}{$\begin{array}{l}\text { Corresponding author: } \\
\text { Nophawu Madikiza, } \\
\text { madikizanophawu@ } \\
\text { gmail.com }\end{array}$} \\
\hline \multicolumn{2}{|c|}{$\begin{array}{l}\text { Received: } 16 \text { Aug. } 2017 \\
\text { Accepted: } 06 \text { Apr. } 2018 \\
\text { Published: } 22 \text { Aug. } 2018\end{array}$} \\
\hline \multicolumn{2}{|c|}{$\begin{array}{l}\text { How to cite this article: } \\
\text { Madikiza, N., Cekiso, M.P., } \\
\text { Tshotsho, B.P. \& Landa, N., } \\
\text { 2018, 'Analysing English } \\
\text { First Additional Language } \\
\text { teachers' understanding and } \\
\text { implementation of reading } \\
\text { strategies', Reading \& Writing } \\
\text { 9(1), a170. https://doi.org/ } \\
\text { 10.4102/rw.v9i1.170 }\end{array}$} \\
\hline \multicolumn{2}{|c|}{$\begin{array}{l}\text { Copyright: } \\
\text { (C) 2018. The Authors } \\
\text { Licensee: AOSIS. This } \\
\text { is licensed under the } \\
\text { Creative Commons } \\
\text { Attribution License. }\end{array}$} \\
\hline \multicolumn{2}{|l|}{ Read online: } \\
\hline 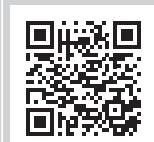 & $\begin{array}{l}\text { Scan this QR } \\
\text { code with your } \\
\text { smart phone or } \\
\text { mobile device } \\
\text { to read online. }\end{array}$ \\
\hline
\end{tabular}

Despite the fact that comprehension plays an important role in the reading process, the literature in a South African context reveals that learners continue to struggle with it and teachers continue to neglect it in their teaching. The literature has further shown that teachers' neglect of comprehension in their reading lessons could be attributed to various reasons, including the fact that teachers seemingly are not taught how to teach reading during their teaching training years. This paper analyses the English First Additional Language teachers' understanding and their implementation of reading strategies in their classrooms to develop teachers' understanding and awareness of the important role played by reading strategies in the reading process. Both quantitative and qualitative approaches were followed and a survey design was used. Purposive sampling was used to select 126 teachers, to whom questionnaires were administered. Statistical Package for Social Sciences software was used to analyse the quantitative data and the qualitative data were analysed thematically. The results indicated that the majority of teachers seemed not to understand certain reading strategies and, therefore, implemented only a few that they understood, greatly limiting learners' potential to explore other reading strategies. The study also established that some teachers only paid attention to traditional reading strategies that did not facilitate comprehension. The study recommended that teachers should be trained on how to teach reading strategies so that they are exposed to a wide range of reading strategies in order to assist learners improve their literacy.

\section{Introduction}

Reading, which is developed through teaching and learning, is an essential skill in modern societies and is crucial for learning in school and beyond (Noor 2016). Within the reading process, comprehension is singled out as a variable that plays a critical role in the reading process. Paris and Hamilton (2009:49) define comprehension as a strategic process in which readers use cues from the text in conjunction with their existing knowledge to make predictions, monitor the predictions and construct meaning from the text. In addition, Pressley (2002) argues that good text comprehension emerges if a reader is able to predict what the text may be about, relates information in the text-to-background knowledge, asks questions while reading, monitors the understanding of the text and summarises what is being read. The relationship between reading comprehension and strategies of readers has long been investigated by various researchers (Gonen 2015; Iwai 2016; Korthof \& Guda 2016; Muijselaar et al. 2017; Yang 2016; Zainal 2008). Cubukru (2007) defines a strategy as an individual's comprehensive approach to a task, including how a person thinks and acts when planning and evaluating his or her study behaviour. Cubukru (2007) further states that a strategy consists of guidelines and rules related to selecting the best tactics and making decisions about their use. Because of the developing interest in the relationship between comprehension and reading strategies, research into the use of reading strategies for improving comprehension has increased over the past decades (Cekiso 2012; Klapwijk 2015; Korthof \& Guda 2016). Muijselaar et al. (2017) are of the view that for reading strategies to be used during text comprehension, metacognitive knowledge of reading is an important prerequisite. However, despite the fact that comprehension plays an important role in the reading process, Klapwijk (2015) is of the view that learners continue to struggle with it and teachers continue to neglect it in their teaching. 
The teachers' neglect of this important element of the reading process (comprehension) could be attributed to various factors. For example, Klapwijk (2015) argues that teachers simply do not seem to view comprehension as part of the reading process, are not able to teach the concept and are seemingly not taught to do so during their teaching training years. Teachers' inability to teach reading has also been observed by Botha et al. (2008), who stated that many teachers in South Africa have underdeveloped understanding of teaching literacy, reading and writing. They further pointed out that many teachers do not know how to teach reading and stimulate reading inside and outside the classroom. This situation is a cause for concern and, therefore, has inspired the researchers to embark on the current study in the context of the Eastern Cape. Specifically, this paper seeks to analyse the English First Additional Language (EFAL) teachers' interpretation or perception of reading strategies and how they teach them in their classrooms. This paper is unique because the literature indicates that many studies have focussed on learners' understanding and their choice of reading strategies (Cekiso \& Madikiza 2014; Li 2010; Sheorey \& Mokhtari 2001). In addition, Waddington (2017) argues that despite the growing body of literature in the field of reading strategies, little work has been done to show how teachers understand reading strategies and how they implement them within their practice. To the best knowledge of the researchers, no study has been conducted on teachers' understanding and implementation of reading strategies, especially in the context of the Eastern Cape. Therefore, little is known about teachers' perception of reading strategies and how they teach them in the context of the EFAL in the Eastern Cape.

\section{Problem statement}

Reading is practical learning and has been seen by Zhou and Zhao (2014) as a hard nut to crack. Their study on reading strategies used by Chinese English Majors revealed that English as a foreign language (EFL) learners were unable to read effectively and frequently failed to comprehend the text. In the context of South Africa, especially in the Eastern Cape, a similar study was conducted by Cekiso and Madikiza (2014). Specifically, their study was conducted in one of the schools in Mthatha District on reading strategies employed by Grade 9 learners, which revealed that the learners from the selected school were not using a wide range of reading strategies and as such found it difficult to understand the printed text. Their study was prompted by the reading challenge that was observed by the teachers from the school who reported that learners were learning without comprehending.

The learners' poor performance in comprehending texts has been revealed by the Annual National Assessment (ANA). For example, the 2011 grades 2-7 ANA results, as reported by the Department of Basic Education (2011), revealed that learners who obtained 'partially achieved' level varied from $30 \%$ to $47 \%$, and those who obtained 'achieved' as a level of performance ranged from $12 \%$ to $31 \%$. In addition, Botha et al. (2008:2) state that the problem of poor reading competency amongst South African learners is that most teachers who are teaching beyond the Foundation Phase are not trained to teach basic reading. Mthatha District has not been immune to the reading crisis that is faced by South Africa. Learners in this district have consistently shown poor performance in literacy assessments conducted since 2011. This has over the years led to interventions by the Eastern Cape provincial department of Teachers' Education in districts to host reading awareness weeks. This points to a high possibility that the reading challenges learners face might be linked to challenges teachers have in understanding and implementing reading strategy instruction. Therefore, this paper seeks to answer the following questions:

- What are EFAL teachers' perceptions of reading strategies?

- What are their reading instruction practices?

\section{Purpose of the study}

Reading has generally held an important place in foreign and second language learning and teaching (Zhou \& Zhao 2014). The assumption is that if teachers understand reading strategies, their learners are likely to understand them too. It is vital for teachers to not only understand reading strategies but also implement them in their classrooms. In this way, teachers would be helping their learners to become independent and confident readers. This study sought to explore teachers' conception of reading strategies and how they teach them so as to provide teachers with information they can use to learn more about reading strategies and improve their classroom practice with regard to reading strategy instruction. Also, the study aimed to describe and analyse the teachers' perceptions of reading strategies.

\section{Reading strategy instruction}

Oxford (2013) points out that EFL and/or ESL educators have long been in search of answers to account for the fact that some students have great difficulty in ESL and/or EFL reading comprehension. As a result, many studies have been conducted to determine what influences the reading comprehension process. While some studies explored the role played by grammar and vocabulary in the reading comprehension process (Akbari 2014; Ma \& Lin 2015; Sidek \& Rahim 2015), other empirical studies focussed on the role played by reading strategies (Sheorey \& Baboaczky 2008; Zhang 2008). The results of such studies have revealed that there is an extensive body of knowledge indicating that teaching students how to use reading strategies can enhance their reading comprehension (Pressley 2002 in Cahoon 2008). Beckman (2002:3) believes that strategy instruction involves teaching students about strategies, teaching them how and when to use strategies and encouraging them to make strategic behaviours part of their learning schema. Cahoon (2008) views teachers' use of reading strategies to be an effective way to help students improve their comprehension of content. In addition, Laughridge (2011) argues that the ultimate goal of classroom reading instruction is to promote self-regulated readers who possess the skills and strategies to 
comprehend what they read and to develop metacognition to know when and how to apply the strategies.

According to Cekiso (2012:1), comprehension strategy instruction, including multiple reading strategies, has been justified for being beneficial in helping learners become strategic readers and improve their reading comprehension. In the South African context, the need for reading strategy instruction should be seen in the poor reading performance of the learners at primary, high school and tertiary levels. Thus, it is necessary for teachers to provide learners with reading strategy instruction that focusses on teaching reading strategies that can help them become strategic readers (Cekiso 2012). This sentiment is also echoed by William and Burden (1997), who point out that English language teachers should go beyond the transmission of knowledge to the empowerment of students by helping them to acquire the knowledge, skills and strategies needed to become autonomous learners who can take responsibility for their own learning. According to Cofu (2013), in South Africa teachers have significant difficulties in implementing the reading strategies to achieve the levels of competencies as required by curriculum assessment policy statement (CAPS) strategies to learners. To address this challenge, Cofu (2013) is of the view that teachers need extensive knowledge and specialised skills, which were not offered during their initial training.

A study conducted by Martinez (2011) points out that literature on metacognitive awareness of reading strategies indicates the need to increase understanding of readers' metacognitive knowledge about reading strategies so that individuals develop into active and constructively responsive readers. According to Mokhtari and Reichard (2002), unskilled readers lack the metacognitive strategic awareness and monitoring of the comprehension process, and these less successful readers are often unaware of their own cognitive process (Garcia 1998; Mokhtari \& Reichard 2002). Mokhtari and Reichard (2002) also point out that students must be helped to acquire and use the reading strategies that have been identified as successful.

Considerable research has shown that the use of a reading comprehension strategies in the learning of second language has positive effects on students' reading comprehension performance (Noor 2016). In addition, Ness (2011) argues that teachers need to teach a variety of reading strategies to enhance students' abilities in reading comprehension. Therefore, according to Ness, it is important to develop teachers' deeper understanding of their reading instruction. The results of a study conducted by Ballou (2012) on explicit strategy instruction revealed that the students' ability to use a wide variety of strategies increased after receiving explicit strategy instruction. The literature has revealed that more proficient readers employ many different reading strategies such as guessing, identifying main ideas and focussing on text structures, while less proficient readers use fewer reading strategies (Klapwijk 2015; Westby 2004). Therefore, the teacher's role in the development of the learners' reading comprehension is important. However, Priestley (2011) and
Swanepoel (2009) in Klapwijk (2012) argue that initiatives aimed at the implementation of educational change fail regularly, often because teachers' role in the change process is underestimated. Hence, the focus of the current study has already been mentioned above.

\section{Research methodology}

This study used both quantitative and qualitative approaches. The aim of using both approaches was an attempt to produce results that could bring insight and be generalised regarding the perceptions of senior phase EFAL teachers' understanding and implementation of reading strategies in the Mthatha Education district. A survey research design was used in this study. It was chosen so that the information gathered from the 126 EFAL teachers' responses could be inferred. The purposive sampling technique was used to select 126 teachers to whom questionnaires were administered during data collection. The teachers were all from the Mthatha Education district. Out of 126 EFAL teachers, six teachers were selected voluntarily to participate in the interview process.

\section{Participants}

In this study, the participants comprised senior phase teachers teaching English as First Additional Language in the Mthatha district in the Eastern Cape. They were all senior phase teachers. In the context of South Africa and by the time this study was conducted, senior phase was from Grade 7 to Grade 9. All teachers (126) were speaking isiXhosa as their mother tongue. The sample consisted of 86 females and 40 males. Their qualifications ranged from diploma to junior degree. The researchers looked at the teachers' understanding and implementation of reading strategies in their classrooms.

\section{Instrumentation}

The study used interviews and questionnaires as methods of data collection. To address the first research question, the study employed a qualitative approach. Specifically, teachers' perceptions or understanding of reading strategies was examined through the use of semi-structured interviews. Gill et al. (2008) describe a semi-structured interview as consisting of several key questions that not only help define the areas to be explored but also allow the interviewer or interviewee to diverge to pursue an idea or response in more detail. This data collection method was deemed suitable for the first research question as it sought to understand how teachers perceived reading strategies.

To address the second research question on teachers' implementation of reading strategy instruction, questionnaires were distributed to 126 EFAL teachers from Mthatha district. According to Godwin and Harry (2009:1), a questionnaire is a set of systematically structured questions used by a researcher to get the required information from respondents. A questionnaire is any written document that presents 
respondents with a series of questions or statements to which they are to react either by writing out their answers or selecting from amongst existing answers. There were 36 reading strategies in the questionnaire that were presented to teachers to evaluate their understanding and implementation of reading strategies. These strategies were divided into three categories as guided by the three stages of reading (pre-reading, during-reading and post-reading), which were compressed into different categories for better understanding. When grouping these strategies, some were overlapping and could fit into both pre-reading and during reading stages and some could fit into during reading and post-reading stages or sometimes to all three stages. These were then put into either fitting category. There were 6 pre-reading and 20 during-reading strategies that were divided into two categories: strategies that analyse the level of understanding and strategies that involve inferences, and the 10 postreading strategies were also divided into two categories strategies that analyse the level of understanding and strategies that deal with summarising the text. The teachers had to rate how a reading strategy pertained to themselves on a Likert scale of 1 (which meant 'I never do this') to 5 (which meant 'I always do this'). For ease of coding, the above statements were collated into Likert scale categories.

\section{Collated raw responses}

The 5-point Likert scale categories were combined as follows:

- Agree: 4 and 5 = I usually do this and I always do this.

- Sometimes: 3 = From time to time I do this.

- Disagree: 1 and 2 = I never do this and I almost never do this.

\section{Data analysis}

According to Maree (2008), qualitative data analysis involves working with data, organising them, categorising them into manageable units, synthesising them, searching for patterns, discovering what is important and coming to reliable conclusions about the data. In this study, the researchers used the manual method to analyse the data generated from the six participants through interviews. The researchers read through the data and became familiar with it. The next step was to examine the data in detail and to provide detailed descriptions of what the participants have said; this was followed by coding and categorising the data and grouping them into themes. On the other hand, the quantitative data collected through questionnaires were analysed by using Statistical Packages for Social Sciences (SPSS) version 22 for data capturing, presentation, analysis and interpretation. The data analysis is in line with the instrument that was used (questionnaire) in the collection of data. As already mentioned above, the data were from 126 teachers from Mthatha. The sample consisted of 86 females and 40 males. The questionnaire protocols on reading strategies, understanding and use were reduced to meaningful units through the use of SPSS version 22 to divulge contributions made by teachers.

\section{Findings Qualitative data}

The focus of the first research question was to establish the EFAL teachers' understanding or perceptions of reading strategies. Specifically, the researchers were interested in establishing whether teachers from the selected district knew what reading strategies were. These EFAL teachers were asked to share their own understanding of reading strategies. Most teachers seemed to be of the view that reading strategies are ways that can be used by learners to comprehend a text. Others stated that reading strategies were techniques that helped in effective reading, and they aided learners to be critical thinkers. Based on their responses, it was clear that teachers understood what reading strategies were and when they were used.

Responding to this question, one teacher explained that:

'Reading strategies involve how one embarks on reading and how teachers go about teaching reading to the learners. These are techniques that both teachers and learners employ in class for meaningful and effective reading. The ideal reason for the use of reading strategies is to understand the text.' [Teacher A, Iqhayiya Secondary School]

To the very same question, another teacher seemed to agree with the above teacher as she explained:

'Reading is a very critical skill that needs both the teacher and the learners to master in order to achieve the desired outcome. Therefore, reading strategies are the different ways a teacher employs in her/his class in order that learners are able to read with understanding. This means that learners will be able to comprehend the text.' [Teacher C, Shooting Star Secondary School]

As part of teachers' understanding of the reading strategies, the researchers were also interested in the reading strategies teachers were using in their classrooms. Most teachers mentioned individual, shared group reading or even reading aloud for the learners as reading strategies that they used in class. In trying to share reading strategies employed in the class, some teachers went as far as giving the different stages of reading including before the actual reading (pre-reading), while reading (during reading) and after the reading has taken place (after reading) strategies, but it was quite evident that they knew reading strategies as they mentioned them in their explanation. Each stage was provided with reading strategies that went with it. Amongst reading strategies mentioned were skimming, scanning, predicting or guessing what will happen, visualising or forming mental pictures, summarising, identifying the most important ideas and restating them on their own.

Responding to this question, Teacher A from Iqhayiya Secondary School said:

- Pre-reading: it includes activating background knowledge, predicting or guessing, skimming and scanning of the text.

- During reading: it refers to close reading of the text supported by the teacher, inference, language use, imagery 
or formulating mental pictures, focus on word choice, Identifying the most important ideas and restating them on their own.

- Post-reading: this refers to interpreting the text as a whole using strategies like summarising, comparing and contrasting, inference, drawing conclusions and expressing opinions.

Responding to the question on reading strategies that teachers adopted in their classes, one teacher commented:

'My strategy is to give my learners a text and then read for them to model what I am doing; they will read individually to check if they were listening to me. I also train the learners to work as partners or groups as this helps them to learn freely without feeling the pressure from the teacher.' [Teacher B, Ilithalethu Secondary School]

When the learners finally meet with the teacher for reading and answering questions on the text they have read, they display more confidence.

Teachers were asked to give reasons why they thought the reading strategies they adopted in their classes were important. Many teachers claimed that the strategies they adopted in class were important because they helped them improve reading in learners. Reading strategies were also said to be important because they brought greater meaning and understanding to what learners had read. They also claimed that reading strategies encouraged the learners to talk about the text and use the text's vocabulary fruitfully and at the end involve them in trying to reproduce the genre in a written text on their own. The teachers said frequent talking about what the learners read helps them understand the text better. Keeping on asking the learners' questions to check their level of understanding about what they have read improves their level of English proficiency, which was another common thread amongst the 10 teachers.

Some teachers also mentioned that there were those strategies that they were still struggling with like tonal variation and were still working on them. The following extracts support the explanation above:

'Reading Strategies help learners to demonstrate different purposes for reading for an example reading for understanding or when they are reading for test purposes. As much as reading for fun is important learners must be able to pinpoint important aspects of the text. Vocabulary increases with reading, Language structures are also identified in the text i.e. parts of speech. These reading strategies make learners understand relevance of the previous reading to the one that they are reading. Learners make sense of what they are reading through reading strategies that they employ in class.' [Teacher D, Excel Secondary School]

A response to the question on why teachers thought the reading strategies they adopted in their classes were important was the following:

'These reading strategies encourage learners to engage with the text and the vocabulary in the text is used correctly which indirectly improves their level of English proficiency. As much as I am still struggling with some reading strategies like tonal variation, the few that I am adopting seem to be working for my learners. My learners are now able to comprehend the text given to them and show interest in reading.' [Teacher E, Thembelihle Secondary School]

The six teachers were asked to list and describe any five reading strategies that they felt were important and also to provide any reading activities that addressed each of the five reading strategies they would have mentioned. It was evident that some teachers amongst this group were aware of only a few strategies. Teachers concurred with each other as they believed the important reading strategies to be employed in class were to read aloud, share the reading, group reading or simultaneous reading as one teacher has put it, individual reading, reading intensively which promotes a lot of practice for learners.

Two teachers differed from other teachers as they gave a number of different strategies from the group. These reading strategies ranged from skimming the text, making inferences and visualising to summarising the text.

The following are marked deliberations by Teacher C, Thembelihle Secondary School:

- Shared reading: the teacher divides the class into smaller groups.

- Reading aloud: the teacher first reads aloud to the class while learners are listening.

- Group reading: the learners read aloud in groups.

- Individual reading: the teacher asks learners to read aloud individually.

- A short story is a good example of an activity that can go with my reading strategies as it captures learners' interest and provides tone variations.

- Reading intensively: too much reading that makes a learner to practise more.

Reading strategies shared by Teacher E from the Shooting Star Secondary School were:

- Skimming: a reading technique used to gather information. One runs through the text, picks up the ideas that draw the attention.

- Scanning: this is used to find specific information, read the passage to find the answer, ignore unrelated information. Activities like word puzzles for skimming and scrabble for scanning were mentioned.

- Predicting Reading: guessing on what the text is all about, some of the predictions may be true.

- Reading without dictionaries: use of clues to predict the meaning of words.

Teacher F from the Iqhayiya School stated:

- 'I think for me reading for competition - where learners have to compete at a higher level like readathon (pronunciation of words, tonal variations and dictionary work are activities associated with this reading strategy).'

- 'Reading with comprehension-learners answer contextual questions (picture analysis can be one of the activities to be used with this strategy).' 
- 'Reading for enjoyment - learners read for leisure but fluency and vocabulary are being developed. Interesting books like magazines with celebrities, newspapers and folklores as activities that goes with this reading strategy).'

- 'Reading with understanding - being able to answer questions.'

- 'Observing punctuation marks - to make sense of what the learner reads.'

- 'Summarising the text - it is when a reader uses his or her own words to retell the story.'

- 'Underlining difficult words - marking important words.'

- 'Meaning of difficult words - using dictionary or guessing the meaning.'

The last deliberation on important reading strategies is from Teacher A of Imfundo School, who mentioned the following strategies:

- 'Making inferences: learners take what they know using clues from the text and think ahead to make judgments. It is simple the speculation of what is to come or said. Guess work will be an activity I can use and underlining difficult words and creation of own dictionary for all inferred words in class.'

- 'Visualising and/or forming mental pictures: it brings a text to life, engages the imagination and use of all senses, Learners create a mental image from the text that is read. The activity I can use is to tell the learners to close their eyes and think of a situation or maybe describe a character using their own imagination.'

- 'Summarising: learners are taught how to identify the most important ideas and restate them in their own words. There is also retelling of a story that learners have heard before teaching them how to summarise. I can also tell them to look at a story's features like the title, character, place and time and briefly tell me what they think happened there before we even actually read the story.'

From the above responses, it was clear that teachers understood what reading strategies were. However, it was also clear that their understanding was only limited to the traditional way of teaching reading. For example, their focus was on teaching oral reading. The literature has revealed that focussing only on oral reading does not address the problem of reading comprehension but only assists with elements like observing punctuation marks, pronunciation and determining reading speed. Such elements of the reading process play a limited role as the major aim of reading is comprehension. Few teachers mentioned reading strategies such as making inferences, summarising and visualising. Only one teacher out of six mentioned important reading strategies like guessing at the meaning of unfamiliar words. Instead they only mentioned the use of dictionaries which might force the learners to read at a word level and disregard context.

\section{Quantitative data}

The second research question focussed on establishing the reading instruction practices of the EFAL teachers. Specifically, the focus was on how EFAL teachers implemented or adopted reading strategies in their classrooms. Teachers completed a questionnaire, which served as a snapshot of their practices. The tables below show reading strategies from three different categories that were said to be both preferred and not preferred by EFAL teachers. The reading strategies were divided into pre-reading, during-reading and post-reading categories.

\section{Pre-reading strategies}

Table 1 below focusses on the reading strategies that teachers encourage their learners to use before the reading process. Such reading strategies are important as they seek to sensitise learners to the text.

In Table 1, 6 out of 36 items are pre-reading strategies. The pre-reading strategies comprised skimming the text by first noting characteristics such as length and organisation, to always read the title, subheadings, references and so on, using one's previous knowledge to guess what is not explicitly stated in the text, decide what to read closely and what to ignore, thinking about what one knows to help one understand what one is reading and bringing what you know into what you are reading. Four of these strategies seemed to be most preferred, one unconvincingly preferred and the other being least preferred by the teachers. A total of $69.6 \%$ of the respondents agreed that the most important reading strategy out of all six pre-reading strategies was to always read the title, subheadings and references. The reason for this response could be that the teachers knew that a title gives direction as well as understanding to what is written or going to be read. It also creates eagerness or lack of interest to read a text.

The next two reading strategies that were equally important with $59.2 \%$ respondents focussed on how learners manipulate their background to understand what they read. The above

TABLE 1: Pre-reading or before-reading strategies.

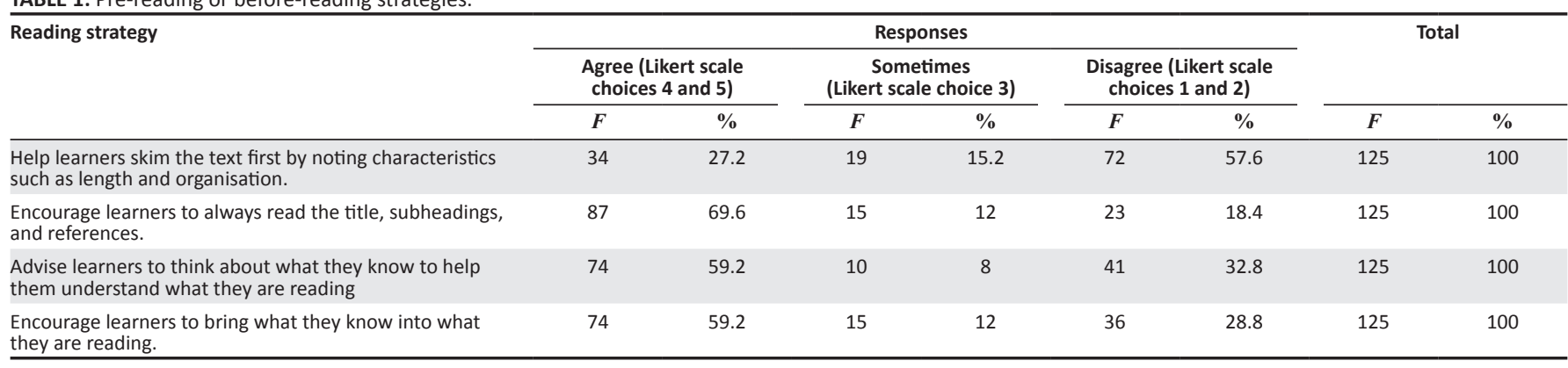


strategies mention almost the same thing, for example, taking acquired knowledge and using it to relate to what one is reading. The teachers' agreement to the use of these strategies could be because they understand that their learners bring to class knowledge acquired before they even started to attend school and they are motivated to apply it during reading (Fillmore \& Snow 2000:8). The respondents felt that skimming the text was least important to their classes; hence, $57.6 \%$ did not agree with this strategy; only $27.2 \%$ agreed to encourage their learners to skim the text before reading. It raises the concern of the researcher that there was such a low percentage of teachers who encouraged their learners to skim the text seeing that skimming is one of the most important techniques to read the text faster and helps one to focus on understanding the main idea and concept of the text, 'structure, organisation and gist' (Spafford \& Grosser 2005:14). One of the reasons for this could be that teachers are not aware that skimming is one of the reading strategies or they know but are not even able to implement it.

\section{During-reading strategies}

Table 2 below focusses on the reading strategies that teachers claim to teach their learners during the reading process. Specifically, the focus is on the activities in which teachers engage their learners during reading.

Table 2 indicates that 20 out of 36 items are during-reading strategies. What this means is that the reading strategies that made up $55.5 \%$ of the questionnaire items were during-reading strategies. In the during-reading strategy, respondents were supposed to respond to 20 questions. The questions focussed on what teachers did during the reading lessons. A total of $74.4 \%$ of the respondents felt that the part that the learners did not understand when they read should not be skipped. The teachers seemed to accentuate to their learners not to leave out parts of the text that they did not know. This could be because learners would miss relevant parts of the text. The second highest with $68.8 \%$ was the use of clues to help learners better understand what they were reading.

The emphasis by the teachers on the use of clues when reading could mean that they were aware that clues could serve as guidelines to what learners were reading. The third strategy, with $64.8 \%$, was that when parts of the text become difficult they re-read the difficult parts to increase their understanding. Re-reading of the text may be beneficial to the learners as they may appreciate the language used in the text. All three of the reading strategies above focus on understanding of the text read. This could mean that the teachers' concern during reading was to influence their learners into comprehending the text more than the other strategies.

Regarding the reading strategy of whether teachers encourage their learners to use dictionaries to look up for words they did not know, $44 \%$ of the respondents agreed to be implementing it and $16.8 \%$ sometimes allowed the use of dictionaries, while $39.2 \%$ of the respondents disagreed with the use of dictionaries to look up for words learners did not know. The assumption to this response could be that learners from these schools did not have dictionaries, and the majority of these schools are in rural areas where even parents do not understand the necessity of buying dictionaries for their children.

The least strategy, with $36.8 \%$ respondents, is 'utilised information in the text to understand what is not directly stated'. This statement is supported by $40.8 \%$ who felt it was not important and, therefore, disagreed that it was important. Furthermore, $48 \%$ of the respondents disagreed with using facts in the text and their previous knowledge to help learners understand the text.

\section{Post-reading strategies}

Table 3 below focusses on the reading strategies that teachers encourage their learners to use after the reading process.

Table 3 revealed that 10 out of 36 items are post-reading strategies. What this means is that the post-reading strategies made up $27.7 \%$ of the questionnaire items. In the analysis of post-reading strategies, the strategy 'To go back and read things over when learners do not understand what they are reading', 72\% respondents indicated they implemented it, while $4.8 \%$ indicated that they sometimes implemented it. This could mean that the learners in this district were encouraged to read for understanding by their teachers.

TABLE 2: During-reading strategies.

\begin{tabular}{|c|c|c|c|c|c|c|c|c|}
\hline \multirow[t]{3}{*}{ Reading strategy } & \multicolumn{6}{|c|}{ Responses } & \multirow{2}{*}{\multicolumn{2}{|c|}{ Total }} \\
\hline & \multicolumn{2}{|c|}{$\begin{array}{l}\text { Agree (Likert scale } \\
\text { choices } 4 \text { and 5) }\end{array}$} & \multicolumn{2}{|c|}{$\begin{array}{l}\text { Sometimes } \\
\text { (Likert scale choice 3) }\end{array}$} & \multicolumn{2}{|c|}{$\begin{array}{l}\text { Disagree (Likert } \\
\text { scale choices } 1 \text { and 2) }\end{array}$} & & \\
\hline & $F$ & $\%$ & $F$ & $\%$ & $F$ & $\%$ & $F$ & $\%$ \\
\hline $\begin{array}{l}\text { 1. Encourage learners to use a dictionary to look up words } \\
\text { that they do not know. }\end{array}$ & 55 & 44 & 21 & 16.8 & 49 & 39.2 & 125 & 100 \\
\hline $\begin{array}{l}\text { 2. Guide learners on how to use facts in the text and their } \\
\text { previous knowledge to help them understand the text }\end{array}$ & 47 & 37.6 & 18 & 14.4 & 60 & 48 & 125 & 100 \\
\hline $\begin{array}{l}\text { 3. Encourage learners to use information in the text } \\
\text { to understand what is not directly stated. }\end{array}$ & 46 & 36.8 & 28 & 22.4 & 51 & 40.8 & 125 & 100 \\
\hline $\begin{array}{l}\text { 4. Encourage learners to use context clues to help them } \\
\text { better understand what they are reading. }\end{array}$ & 86 & 68.8 & 10 & 8 & 29 & 23.2 & 125 & 100 \\
\hline $\begin{array}{l}\text { 5. Ask learners to skip the part they do not understand } \\
\text { when they are reading. }\end{array}$ & 93 & 74.4 & 8 & 6.4 & 24 & 19.2 & 125 & 100 \\
\hline $\begin{array}{l}\text { 6. Encourage learners to re-read to increase their } \\
\text { understanding when parts of the text become difficult. }\end{array}$ & 81 & 64.8 & 17 & 13.6 & 27 & 21.6 & 125 & 100 \\
\hline
\end{tabular}




\begin{tabular}{|c|c|c|c|c|c|c|c|c|}
\hline \multirow[t]{3}{*}{ Reading strategy } & \multicolumn{6}{|c|}{ Responses } & \multirow{2}{*}{\multicolumn{2}{|c|}{ Total }} \\
\hline & \multicolumn{2}{|c|}{$\begin{array}{l}\text { Agree (Likert scale } \\
\text { choices } 4 \text { and } 5 \text { ) }\end{array}$} & \multicolumn{2}{|c|}{$\begin{array}{c}\text { Sometimes } \\
\text { (Likert scale choice 3) }\end{array}$} & \multicolumn{2}{|c|}{$\begin{array}{l}\text { Disagree (Likert } \\
\text { scale choices } 1 \text { and 2) }\end{array}$} & & \\
\hline & $F$ & $\%$ & $F$ & $\%$ & $F$ & $\%$ & $F$ & $\%$ \\
\hline $\begin{array}{l}\text { 1. Tell learners to think up of questions to test how well } \\
\text { they understand what they are reading. }\end{array}$ & 83 & 66.4 & 19 & 15.2 & 23 & 18.4 & 125 & 100 \\
\hline $\begin{array}{l}\text { 2. Ask learners to go back and read things over when } \\
\text { they do not understand what they are reading. }\end{array}$ & 90 & 72 & 6 & 4.8 & 29 & 23.2 & 125 & 100 \\
\hline $\begin{array}{l}\text { 3. Encourage learners to summarise the main concept } \\
\text { of what they read. }\end{array}$ & 87 & 69.6 & 11 & 8.8 & 27 & 21.6 & 125 & 100 \\
\hline
\end{tabular}

'To summarise the main concept of what one reads' was another strategy that seemed to be preferred by the teachers, with $69.6 \%$ respondents indicating that they have been implementing the strategy while $8.8 \%$ of teachers confirming that they sometimes implemented the strategy and $21.6 \%$ confirming that they never encouraged their learners to use the strategy. It is assumed that the majority of learners in this district should be able to read for understanding if the teachers' assertion is anything to go by.

The next strategy, which was equally preferred by the teachers, was 'to think up of questions to test how well learners understand what they are reading'. A total of $66.4 \%$ respondents agreed to having been encouraging their learners to use the strategy, while $15.2 \%$ sometimes and $18.4 \%$ of the teachers could not have been implementing this strategy. The implementation of the above strategy by the teachers could mean that the learners were encouraged to critically engage with what they were reading as well as discovering how much they comprehended. The other reason for encouraging learners to think of questions to test how well they understood what they were reading could mean that the teachers wanted self-sufficient learners who appreciated the importance of analysing and describing the text.

\section{Discussion of findings}

This study sought to establish teachers' understanding and implementation of reading strategies in their classes. The objective was to establish teachers' understanding of reading strategies. The results indicated that teachers understood what reading strategies were. However, they were using quite a small number of reading strategies and also focussed on the traditional reading strategies that did not facilitate reading. Similar findings were obtained by Cekiso (2017) in a study that was conducted on teachers' perceptions of their reading strategies instruction in a similar context to the current study. Cekiso's study revealed that the majority of teachers were not adequately prepared to teach reading, and they only paid attention to oral reading without paying attention to reading comprehension. A teachers' knowledge of a limited number of reading strategies has been revealed by a study conducted by Cahoon (2008) who observed that reading strategies were not necessarily being implemented by teachers on a consistent basis.

The study further established that teachers claimed to implement pre-reading strategies more than during-reading and post-reading strategies. This could be because teachers understood that the title, subheadings and references helped learners get a sense of direction on what was going to be read, and learners became eager to read thereafter. These findings are supported by Beers (2003) who concluded that pre-reading strategies help learners think actively throughout the reading process instead of trying to make sense of the text at the conclusion. Teachers from the selected district seemed to acknowledge the importance of prior knowledge when one comprehends a text. This knowledge, as indicated by Cromley and Azevedo (2007), assists the student when meaning breaks down during the reading process. The findings of the study also sit well with the argument by Fisher and Frey (2009) that prior and background knowledge constituted the missing link in effective comprehension.

The skimming of the text proved to be less employed by the teachers. This could be related to the belief that skimming reduces overall comprehension of the read passage as the reader reads only a part of the text (Beale 2013). However, this seems to ignore the benefits associated with skimming, such as that with skimming there is potential to read more in less time (Beale 2013). Findings on the during-reading stage show that the three most important strategies employed by the teachers have everything to do with metacognition (awareness and understanding of one's thought processes). The key issues were that teachers discouraged learners from skipping the parts that they did not understand when read. Furthermore, teachers encouraged learners to use clues to help learners better understand what they were reading. Teachers could be encouraging their learners to employ this strategy because they understand that clues give guidance and shed light on what one is reading. In support of these findings, Benchmark Education (2015:3) highlights that other ways to improve comprehension during reading are to make connections, make predictions, make inferences, use context clues, use text features, identify text structures, use graphic organisers to pinpoint particular types of text information and write comments or questions on self-stick notes or in the margins. Furthermore, to increase learners' understanding regarding the re-reading of difficult parts of the text that was another strategy that learners were encouraged to use, a strategy that Karpicke, Butler and Roediger (2009) found to be both effective and popular with learners.

\section{Conclusions and recommendations}

We conclude, on the basis of findings discussed above, that teachers seemed to encourage their learners to employ certain 
reading strategies. However, very few reading strategies are understood and implemented before, during and after reading. As the majority of teachers were not competent in teaching reading strategies, it is important that teachers undergo a training session on how to teach reading strategies for the purpose of facilitating learners' understanding of text. Teachers' understanding of and ability to implement strategies in the reading process are important skills for them to master as they are the medium to transfer this knowledge to the learners; they can do this only if they themselves are empowered with reading strategies. Most of the strategies were not understood by teachers and, therefore, their implementation was compromised. We, therefore, recommend that teachers from this district employ and expose their learners to a variety of reading strategies to be able to prepare readers for efficient reading. Overall, for teachers to help their learners develop strong reading skills and habits, they themselves need to improve their own reading skills, and hence the need for teacher training and retraining on reading strategies.

\section{Acknowledgements}

The authors thank the teachers who participated in the study.

\section{Competing interests}

The authors declare that they have no financial or personal relationships which may have inappropriately influenced them in writing this article.

\section{Authors' contributions}

N.M. was responsible for conceptualising the title of the manuscript and collected and analysed the data. M.P.C. was responsible for the introduction, presentation and discussion of findings and collated the manuscript. B.P.T. was responsible for the literature review. N.N. was responsible for the methodology section.

\section{References}

Akbari, Z., 2014. 'The role of grammar in second language reading comprehension: Iranian ESP context', Procedia-Social and Behavioural Sciences 98, 122-126. https://doi.org/10.1016/j.sbspro.2014.03.397

Ballou, A.K., 2012. 'Using explicit strategy instruction to improve reading comprehension', unpublished Master's Dissertation, St. John Fisher College, Pittsford, NY.

Beale, A., 2013. Skimming and scanning: Two important strategies for speeding up your reading, viewed 14 March 2017, from http://www.howtolearn.com/2013/02/ skimmingand-scanning-twoimportant-strategies-for-speeding-up-your-reading

Beckman, P., 2002. Strategy instruction. ERIC digest (Digest number E638), ERIC Document Reproduction Service No. ED 474302, ERIC Clearinghouse on Disability and Gifted Education, Council for Exceptional Children, Arlington, VA.

Beers, K., 2003. When kids can't read: What teachers can do? Heinemann, Portsmouth, $\mathrm{NH}$.

Benchmark Education, 2015. What is metacognition? viewed 16 March 2015, from https://benchmarkeducation.com/best-practices-library/metacognitive-strategies. html\#Section_1

Botha, D., Bizos, N., Gains, P., Moris, D., Place, J. \& Puwani, H., 2008. National reading strategy, Department of Education, Republic of South Africa, Pretoria.

Cahoon, B., 2008. 'Teachers teaching teachers about content area reading strategies and their perceptions of the effectiveness of these strategies', unpublished MEd dissertation, University of Manitoba.

Cekiso, M., 2012. 'Reading comprehension and strategy awareness of Grade 11 English Second Language learners', Reading \& Writing 3(1), 1-8. https://doi.org/10.4 102/ rw.v3il.23
Cekiso, M., 2017, 'Teachers' perceptions of reading instruction in the Eastern Cape', Reading \& Writing Journal 8(1), 1-8.

Cekiso, M. \& Madikiza, N., 2014. 'Reading strategies used by grade 9 English Second Language learners in a selected school', Reading \& Writing 5(1), Art. \#42, 1-7.

Cromley, J.G. \& Azevedo, R., 2007. 'Testing and refining the direct and inferential mediation model of reading comprehension', Journal of Educational Psychology 99(2), 311-325. https://doi.org/10.1037/0022-0663.99.2.311

Cofu, D.P., 2013. 'An exploration of reading strategies implemented by teachers teaching isizulu Home Language in grade 1 ', unpublished Master's dissertation, University of KwaZulu-Natal, Durban.

Cubukru, F., 2007. 'An investigation of reading strategies employed by trainee teachers', GEMA Online Journal of Language Studies 7(2), 95-110.

Department of Basic Education, 2011, Curriculum and assessment policy statement (Grade 7-9): English first additional language, viewed 14 November 2014, from www.thutong.doe.gov.za/Home/PolicyDocuments/tabid/1952/Default.aspx?...1

Fillmore, L.W. \& Snow, C.E., 2000, What teachers need to know about language, Clearinghouse on Language and Linguistics, Special Report, viewed 14 September 2016, from https://people.ucsc.edu/-ktellez/wong-fill-snow.h

Fisher, D. \& Frey, N., 2009, Background knowledge: The overlooked factor in reading comprehension, McGraw Hill Education, viewed 26 March 2017, from https:// www.mheducation.co.uk/media/wysiwg/

Garcia, G.E., 1998, 'Mexican-American bilingual students' metacognitive reading strategies: What's transferred, unique, and problematic?', National Reading Conference Yearbook 47, 253-263.

Gill, P., Stewart, K., Treasure, E. \& Chadwick, B., 2008. 'Methods of data collection in qualitative research, interviews and focus groups', British Dental Journal 204(6) 291-295. https://doi.org/10.1038/bdj.2008.192

Godwin, V.O. \& Harry O.O., 2009. Questionnaire as a data collection instrument, viewed 27 September 2015, from http://onganya.blogspot.co.za/2010/03/ questionnaire-as-data-collection.html

Gonen, I.K., 2015. 'The relationship between FL reading strategies and EFL reading proficiency: A study on Turkish EFL learners', Educational Research and Reviews 10(24), 2924-2936. https://doi.org/10.5897/ERR2015.2530

Iwai, Y., 2016. 'Promoting strategic readers: Insights of preservice teachers' understanding of metacognitive reading strategies', International Journal for the
Scholarship of Teaching and Learning 10(1), 1-7. https://doi.org/10.20429/ ijsotl.2016.100104

Karpicke, J.D., Butler, A.C. \& Roediger, H.L., 2009. 'Metacognitive strategies in student learning: Do students practise retrieval when they study on their own?' Memory 17(4), 471-479. https://doi.org/10.1080/09658210802647009

Klapwijk, N.M., 2012. 'Reading strategy instruction and teacher change: Implications for teacher training', South African Journal of Education 32, 191-204. https://doi. org/10.15700/saje.v32n2a618

Klapwijk, N.M., 2015, 'EMC² = Comprehension: A reading strategy instruction framework for all teachers', South African Journal of Education 35(1), 1-10. https://doi.org/10.15700/201503062348

Korthof, E.C. \& Guda, M.C., 2016. 'The relation between reading strategies and reading comprehension', Science Studies of Reading 21(3), 1-4.

Laughridge, V.J., 2011. 'The relationship between professional development and teacher change in the implementation of instructional strategies that support elementary students' science textbook reading', unpublished PhD thesis, University of Nebraska-Lincoln.

Li, F., 2010. 'A study of English reading strategies used by senior middle school students', Asian Social Science 6(10), 184-192. https://doi.org/10.5539/ass. v6n10p184

Ma, Y. \& Lin, W., 2015. 'A study on the relationship between English reading comprehension and English vocabulary knowledge', Education Research International 1(2), 1-14. https://doi.org/10.1155/2015/209154

Maree, K., 2008. First steps in research, Van Schaik Publishers, Pretoria.

Martinez, A.C.L., 2011. 'A review of the literature into ESL/EFL reading strategy research', The Grove 1(2), 261-267.

Mokhtari, K. \& Reichard, C., 2002. 'Assessing students' metacognitive awareness of reading strategies', Journal of Educational Psychology 94(2), 249-259. https://doi. org/10.1037/0022-0663.94.2.249

Muijselaar, M.M.L., Swart, N.M., Steenbeek-Planting, E.G., Droop, M., Verhoeven, L. \& de Jong, P.F., 2017. 'Developmental relations between reading comprehension and reading strategies', Scientific Studies of Reading 21(3), 194-209. https://doi. org/10.1080/10888438.2017.1278763

Ness, M., 2011. 'Explicit reading comprehension instruction in elementary classrooms: Teacher use of reading comprehension strategies', Journal of Research in Childhood Education 25, 98-117. https://doi.org/10.1080/02568543.2010.531076

Noor, N.H.H., 2016. 'Second language comprehension strategies in Brunei Durussalom's schools', unpublished B.Ed. dissertation, The University of Queensland, Australia.

Oxford, R.L., 2013. Teaching \& researching: Language learning strategies, Taylor and Francis, Hoboken.

Paris, S.G. \& Hamilton, E.F., 2009. 'The development of children's reading comprehension', in S.E. Israel \& G.G. Duffy (Eds.), Handbook of research on reading comprehension, pp. 32-53, Routledge, New York.

Pressley, M., 2002. Reading instruction that works: The case for balanced teaching, 2nd ed., Guilford, New York.

Priestley, M., 2011. 'Schools, teachers and curriculum change: A balancing act?', Journal of Educational Change 12, 1-23. https://doi.org/10.1007/s10833-010-9140-z 
Sidek, H.M. \& Rahim, H.A., 2015. 'The role of vocabulary knowledge in reading comprehension: A cross-linguistic study', Procedia-Social and Behavioural Sciences 197, 50-56. https://doi.org/10.1016/j.sbspro.2015.07.046

Sheorey, R. \& Baboazky, E. (eds.), 2008. 'Metacognitive awareness of reading strategies among Hungarian college students', in K. Mokhtari \& R. Sheory (eds.), Reading strategies of first and second-language learners, pp. 167-173, ChristopherGordon, Norwood, MA.

Sheorey, R. \& Mokhtari, K., 2001. 'Differences in the metacognitive awareness of reading strategies among native and non-native speakers', System 29(4), $435-449$

Spafford, C.S. \& Gorsser, G.S., 2005. Dyslexia and reading difficulties: Research and resource guide for working with all struggling readers, 2nd ed., American Instructional College, Pearson, Springfield.

Swanepoel, C., 2009. 'A comparison between the views of teachers in South Africa and six other countries on involvement in school change', South African Journal of Education 29, 461-474.

Waddington, J., 2017. 'Teacher understanding and implementation of motivational strategies in ELT', ELT Journal 4(1), 1-13. https://doi.org/10.1093/elt/ccx044
Westby, C., 2004. 'A language perspective on executive functioning, metacognition, and self-regulation in reading', in C.A. Stone, E.R. Silliman, B.J. Ehren \& $\mathrm{K}$. Apel (eds.), Handbook of language and literacy: Development and disorders, pp. 398-427, The Guilford, New York.

William, M. \& Burden, R., 1997. Psychology for language teachers: A social constructivist approach, Cambridge University Press, Cambridge.

Yang, Y., 2016. 'A research on reading strategies among non-English major postgraduates', English Language Teaching 9(8), 204-212. https://doi.org/10.5539/elt.v9n8p204

Zainal, Z., 2008. 'The relationship between reading comprehension and strategies of readers: A case study of UTM students', Research in English Language Teaching $1(3), 95-118$.

Zhang, L.J., 2008. 'Constructivist pedagogy in strategic instruction: Exploring pathways to learner development in the English as a second language (ESL) classrooms', Instructional Science: An International Journal of the Learning Sciences 36, 89116. https://doi.org/10.1007/s11251-007-9025-6

Zhou, X. \& Zhao, Y., 2014. 'A comparative study of reading strategies used by Chinese English majors', English Language Teaching 7(3), 13-18. https://doi.org/10.5539/ elt.v7n3p13 